\section{Plan S in Latin America: A Precautionary Note}

Humberto Debat

Instituto Nacional de Tecnología Agropecuaria (IPAVE-CIAP-INTA)

Dominique Babini

Consejo Latinoamericano de Ciencias Sociales (CLACSO)
VOLUME 11 / ISSUE 1 / 2020

\begin{abstract}
Background Latin America has historically led a vital and open access movement and leads the worldwide region with the adoption of wider open access practices. Argentina has expressed its commitment to join Plan S, an initiative from a European consortium of research funders with a mandate to promote the open access publishing of scientific outputs.
\end{abstract}

Analysis This opinion article suggests that the potential adhesion of Argentina or other Latin American nations to Plan S ignores the reality and tradition of Latin American open access publishing.

Conclusion and implications Plan S must demonstrate that it will encourage at a regional and global level the advancement of non-commercial open access initiatives. Latin America should invest and promote open nonprofit scholarly-led infrastructures, allowing the academy to regain control of scholarly communications.

Keywords Plan S; Latin America; Open access publishing

\section{Resume}

Contexte Historiquement, l'Amérique latine a été un chef de file dans le mouvement pour fournir un accès aux communications savantes qui soit vital et ouvert.

Aujourd'hui, ce continent demeure un leader mondial en adoptant des pratiques de libre accès qui sont plus englobantes. L'Argentine, notamment, a manifesté son engagement pour se joindre au Plan S, lequel est l'œuvre d'un collectif de bailleurs de fonds européens dont le mandat est de promouvoir l'édition de recherches scientifiques à libre accès.

CISP Journal Services

Scholarly and Research Communication

Volume 11, Issue 1, Article ID 0101347, 12 pages

Journal URL: www.src-online.ca doi: 10.22230/src.2020v11n1a347

Received October 1, 2019, Accepted January 3, 2020, Published February 7, 2020

Debat, Humberto, \& Babini, Dominique. (2020). Plan S in Latin America: A Precautionary Note. Scholarly and Research Communication, 11(1): 0101347, 12 pp.

(C) 2020 Humberto Debat \& Dominique Babini. This Open Access article is distributed under the terms of the Creative Commons Attribution Non-Commercial License (http://creativecommons.org /licenses/by-nc-nd/2.5/ca), which permits unrestricted non-commercial use, distribution, and reproduction in any medium, provided the original work is properly cited.
Humberto Debat is a

Research Scientist at the Institute of Plant Pathology, Center for Agricultural Research of the National Institute of Agricultural Technology of Argentina. Email: debat.humberto @inta.gob.ar.

Dominique Babini is an Open Access Advisor at the Latin American Council of Social Sciences, CLACSO. Email: dasbabini@gmail.com . 


\section{Scholarly and Research}

\section{Communication}

VOLUME 11 / ISSUE 1 / 2020
Analyse Cet article d'opinion suggère que l'adhésion potentielle au Plan S par l'Argentine ou d'autres pays latino-américains ignore la réalité et l'histoire de l'édition à libre accès latino-américaine.

Conclusion et implications Le Plan S doit démontrer qu'il encouragera des initiatives non-commerciales envers le libre accès à un niveau régional et mondial. L'Amérique latine doit investir dans des infrastructures sans but lucratif qui soient ouvertes et menées par des universitaires, de manière à permettre à ceux-ci de reprendre le contrôle sur les communications savantes.

Mots clés Plan S; Amérique latine; Édition à libre accès

\section{Introduction}

Plan $S$ is an initiative by a European consortium of research funders to mandate the open access publishing of research outputs funded by public or private grants; it is intended to become international by 2021. Launched in September 2018 and revised in May 2019, the plan, which is supported by the so-called cOAlition S (2019a), involves 10 principles directed to dictate scholarly publishing in "Open Access Journals, Open Access Platforms, or made immediately available through Open Access Repositories without embargo" (n.p.). cOAlition S (2019b), coordinated by Science Europe and comprising 17 national research funders, five charitable foundations, and the European Research Council, has pledged to implement the 10 principles of Plan S in 2021, and is seeking support from other regions.

Since its inception, Plan $S$ has received multiple and robust critiques regarding its implementation guidelines from diverse members of the scholarly publishing ecosystem, ranging from researchers (Baum \& Coen, 2019; Kowaltowski \& Oliveira, 2019) (including an open letter of approximately 1,800 scientists around the globe [Plan S Open Letter, 2019]), scientific societies (Brainard, 2019; de Knecht, 2019), the Society Publishers' Coalition (2019), nonprofit society publishers (McNutt, 2019; Purdy, Michelangeli, \& Fésüs, 2019), open access and professional publishers (Mudditt, 2019; Pulverer, 2018), consultants (Clarke, 2018), and the European Federation of Academies of Sciences and Humanities (ALLEA, 2018). Concerns about the possible negative impact of Plan S on the Global South have been raised by the Network of Scientific Journals of Latin America and the Caribbean, Spain and Portugal (Redalyc); Ameli Open Knowledge for Latin America and the Global South (AmeliCA) (Becerril-García, 2019); the Latin American Council of Social Sciences (CLACSO) (Sayer, 2019); among others voices (Figshare, 2019). India, which had initially shown interest, has recently decided to skip Plan S and focus on national efforts in science publishing (Mukunth, 2019). As an example of cOAlition $S$ global promotion activities, and setting a precedent in Latin America, a joint communication was released during the 2019 steering committee meeting on cooperation in science and technology between the European Union and Argentina stating that "Argentina will join cOAlition S" (ARG-EU, 2019, p. 1). Considering the economic implications of Plan $S$ for signatories and their research communities, and the fact that the implementation guidelines of Plan S do not demonstrate how publishers will provide transparent costing and pricing (Coalition S, 2019a - principle 5) and acceptable caps for article processing charges (APC), it seems reasonable for Latin America to wait to join Plan S until its first evaluation informs 
results and implications for less privileged countries and institutions. This would give time for further consultations within the region before the signing of an agreement that would impose a significant conversion of funding allocation for scholarly publishing starting no later than 2021. Regional funding restrictions are not trivial. Argentina is in a context of a severe economic crisis and systematic spending cuts on research and development (Carignano \& Jaworski, 2019; Roman, 2018; Wessel, 2019a, 2019b), and medium-term perspectives require the thorough analysis of the costs involved and possible alternatives.

\section{Opinion}

Numerous stakeholders of the research and publishing enterprise share the spirit of Plan S of immediately achieving full open access in scholarly publishing, but many critics of the plan are focused on its implementation guidelines. The potential adhesion of Argentina and other countries from this region to Plan S ignores the reality of Latin America and harms the advancement of non-commercial open access initiatives at a regional and global level. Plan S implementation may encourage scholarly journals to shift to article transaction models dependent on APCs that, in turn, will result in the withdrawal of resource investments in public non-commercial infrastructure for open scientific communications, which are crucial to move toward open science processes and practices in Latin America. While this initiative will influence the publishing ecosystem worldwide, its design has ignored more than 20 years of agenda on open access in the Global South and the paradigm of a contrasting scholarly publishing landscape in Latin America (Becerril-García, 2019).

Plan S guidelines were released without consulting the many stakeholders from diverse fields and institutional backgrounds in different regions of the world. Nevertheless, the 2019 update on the original plan, prompted by more than 600 responses from the research community during an "open consultation" (cOAlition, 2019c) is to be applauded. These queries attenuated some of the requirements of the first version of the initiative (SPARC Europe, 2019), such as that very few of the current open access journals are compliant with Plan S (Frantsvåg \& Strømme, 2019), and that APC-based journals are better positioned to comply with Plan S. Some advances in the updated version of Plan S, outlined in the recent Scholarly Publishing and Academic Resources Coalition (SPARC, 2019) report, are: i) the recognition of repositories as comparable to open access journals and other platforms; ii) the right of authors and/or institutions to retain copyright at no extra cost; iii) a commitment to assess research outputs based on their intrinsic value; and iv) the extension of the deadline to implement the plan from 2020 to 2021.

From a geopolitical perspective, there are fundamental differences in the approach to scientific publishing and scholarly publications. They appear to be handled as a commodity prone to commercialization in Plan S guidelines, while in Latin America they are conceived as the community sharing of public goods. Latin American scholarly publishing is supported by non-commercial and publicly funded infrastructure oriented to advance open access as the natural form of scientific communication. In essence, scientific outputs in Latin America belong to the academy and not to large publishers, with a tradition of free-to-publish and free-to-read collaborative/coopera-

Debat, Humberto, \& Babini, Dominique. (2020). Plan S in Latin America: A Precautionary Note. Scholarly and Research Communication, 11(1): 0101347, 12 pp. 


\section{Scholarly and Research}

\section{Communication}

VOLUME 11 / ISSUE 1 / 2020 tive publishing (Becerrill-García \& Aguado-López, 2018). This is considered a universal right in the region (CLASCO, 2015). For instance, since 2003 the nonprofit organization Red de Revistas Científicas de América Latina y el Caribe, España y Portugal (Redalyc, 2019) has pioneered as an inclusive network of scientific journals of Latin America and the Caribbean, Spain, and Portugal, functioning as a hub for scientific information and contributing to the visibility of journals published in the region. Redalyc (2019) now contains more than a half million full-text articles from 1,260 open access peer-reviewed journals published by 622 publishers from 22 IberoAmerican countries, with an average of four million article downloads per month (Alerpin, 2015, 2016). In addition, Redalyc (2019) supports AmeliCA (2019a) an interinstitutional community initiative involving UNESCO and CLACSO as partners, which pursues a collaborative and sustainable non-commercial enterprise for open knowledge in Latin America and the Global South. AmeliCA (2019b) intends to contribute to the equitable integration of the Global South in the universal dialogue of scientific communication, "recognizing its experience and leadership in defending and contributing to Open Access" (n.p.).

AmeliCA shares the ultimate goal of Plan S, which is taking pivotal large-scale steps to achieve open access, and recognizing a need to review current research assessment schemes in the region (Becerril-García, 2019). AmeliCA recognizes that the traditional practices of research assessment are based on flawed metrics and distorted incentives, and thus, as cOAlition S (2019a), AmeliCA expressed a commitment to the San Francisco Declaration on Research Assessment (DORA, n.d.). However, AmeliCA does not agree with the mandate that funders or universities should cover open access publication fees, saying those resources should be funelled to secure the development of academic infrastructure to take back control of scientific publication by academic institutions (Becerril-García, 2019). Regarding the implementation of resources to sustain open access publishing, Plan S suggests the capping of APC fees and eventual publishing waivers for underprivileged countries, which represents a naïve and condescending partial answer to financial restrictions on publishing for researchers in countries and institutions with limited economic resources. It reveals a patronizing view of scientific sharing that translates into rich countries controlling science and diminishes the Global South as a mere passive observer with no control beyond global commercial agreements between wealthy governments and the few large oligopolist commercial publishers (Becerril-García, 2019; Larivière, Haustein, \& Mongeon, 2015). Plan S overlooks that its mandates affect scholar communication structures from other regions, regardless of whether they sign the initiative. Moreover, waiver policies and APC caps are indifferent to the tradition of non-commercial publishing in Latin America.

For developing regions with no tradition of APCs, this global proposal from cOAlition $S$ (2019a) to accelerate the transition to open access, which follows a previous global proposal called OA2020 (Zhang, 2019), is problematic because it takes for granted that open access is a market, as subscriptions are, and it asks the world to support this implied vision without discussion. Jean-Claude Guédon (2018) says in The History of Open Access and its Meaning, "commercializing scholarly journals profoundly changed their nature and their economic framework: they became a commodity. It was in effect

Debat, Humberto, \& Babini, Dominique. (2020). Plan S in Latin America: A Precautionary Note. Scholarly and Research Communication, 11(1): 0101347, 12 pp. 
a (counter) revolution" (n.p.). Will accelerating the transition to open access once again benefit the industry shareholders, giving them outrageous benefits as with subscriptions? As John Willinsky (2018) mentioned in an interview, "they charge what the market endures" (n.p.). Why not take the opportunity of global proposals such as Plan S to redirect funding, allowing the academic and scholarly community to take back control of scholarly communications? Why not give priority within Plan $S$ to the diversity of academic-led non-commercial venues so as to strengthen them? In its present form, Plan S may end up resulting in a high percentage of budget allocations from cOAlition $S$ members to for-profit venues and APCs.

An undesired consequence of Plan S in developing regions could be the weakening of vulnerable non-commercial open access venues. Latin America has historically led a strong and growing open access movement; it leads the world in the adoption of open access practices (Babini, 2019; Babini \& Machin-Mastromatteo, 2015). Latin American tradition in open access publishing has redounded in new avenues of engagement of scholarly publishing, such as the demand of scientific articles from the public audience (Alperin, 2015). The systematic use of scientific articles by students and the non-academic public observed in the region questions the scientometric assessment of research outputs based solely on citations: the traditional currency for the legitimization of large commercial publishers from the Global North.

The discussion over Plan S as a global proposal for accelerating open access has been pivotal in exposing how unbalanced the debates are-they are mostly circumscribed on the Global North between a condensed elite group involved in the scholarly publishing market (Tennant, 2019). Latin America encourages knowledge as a public good in non-commercial platforms, which reverberates in an unparalleled apprehension of the scholarly record by the general public (Alperin, 2016). Limited resources should be channelled toward maintaining and scaling these not-for-profit initiatives, instead of deliberately infusing money in market-oriented journals.

To contribute to the democratization of knowledge, it is important to promote policies, actions, and funding to implement open access while improving the quality of the scholarly editorial process and ensuring that the scholarly community retains control of it. There is a need to complement traditional bibliometric indicators with novel open access indicators appropriate for regional scenarios and encourage worldwide access to knowledge as a human right (CLACSO, 2015). For instance, Argentina, where public funds finance the majority of the scientific enterprise, has advanced a plethora of initiatives to promote open access (UNESCO, 2017). One example is the National System of Science and Technology Digital Repositories (Argentina, n.d.), which the Ministry of Science created in 2009. It now harbours over 265,817 open access publications under the guidance of the Experts Committee on Digital Repositories of Science and Technology. With the implementation of this repository, the former Argentinean government promoted Act 26,899 (ARG, 2013) which was approved in congress and enacted on December 2013, prioritizing repositories in the path to open access. The essence of this legislation is that knowledge as a public good, financed by society, must be accessible to all citizens. This act states in its second article that Argentinean public organizations and science and technology institutions must establish policies for public

Debat, Humberto, \& Babini, Dominique. (2020). Plan S in Latin America: A Precautionary Note. Scholarly and Research Communication, 11(1): 0101347, 12 pp.
VOLUME 11 / ISSUE 1 / 2020 


\section{Scholarly and Research} Communication

VOLUME 11 / ISSUE 1 / 2020 access management and the long-term data preservation of primary research to ensure the public availability of research outputs.

These actions and initiatives are not region agnostic. Similar repository legislations were simultaneously approved in Peru in 2013 and Mexico in 2014; they were discussed in congress in Brazil but have not yet been approved. In addition, since 2012, public science and technology agencies from Argentina, Brazil, Colombia, Costa Rica, Chile, Ecuador, El Salvador, Mexico, Peru, and Uruguay have joined a regional network of national systems of digital repositories dubbed LA Referencia (n.d.) to reinforce their repositories systems. This federated network is a member of the Confederation of Open Access Repositories (COAR, 2019), which increases interoperability in the region and provides public access to over 1,855,259 documents, including articles, reports, and academic theses. Concerning the Plan S initiative discussion, La Referencia (2019) has issued a document with principles and actions proposed for Latin America recommending "a better balance between funding of resources purchased from commercial companies and the public resources destined to strengthen the national systems and platforms" (p. 9).

In addition, at its first assembly in 2017, the Consortium of National Agencies from Ibero-América (Consorcios de Iberamérica y el Caribe, 2017), which is responsible for the national purchase of journal subscriptions, agreed on a statement indicating that: "an OA expansion policy, through the payment of APC fees, is impossible to undertake from a financial point of view for the participant countries. Not to create grants to pay a publication in OA-APC journals is recommended to the institutions" (p. 2). With this vision, which is in line with the tradition of collaborative/cooperative information systems in Latin America and considering the present severe economic restrictions in regional research budgets, the Argentinean government's decision to join Plan S should be postponed until the results of the initiative's first evaluation in 2024 show that the funds are also directed to build a more inclusive, participatory, and non-commercial global open access future.

The guidelines of Plan S, in both its original and revised versions, fail to tackle the essential and chronic issues of traditional scholarly publishing, such as the concentration of articles in large international commercial publishers with extraordinary profit margins (Grossman \& Brembs, 2019) that are subsidized with both research money and free labour. A reasonable APC for a research institution in the Global North will most likely be unaffordable and unreasonable for an institution in a developing region (Sayer, 2019). Given that legacy publishers-with their important share of the scholarly publishing landscape and influence in research evaluation indicators-will most likely shift from a subscription-based model to APCs, it is becoming more evident that Plan $S$ will eventually pave the way to a collective and global pay-to-publish system. As stated by the OA2020 Mainland China signatory libraries responding to Plan S guidance on implementation (Zhang, 2019), it is important to "avoid the perverse effect of giving no-fees journals an incentive to start charging fees" (n.p.). As of today, 70 percent of open access journals in the Directory of Open Access Journals (DOAJ, 2020) do not charge APCs. In other words, Plan S could imply a direct transfer of funds to support the cost of publishing from research toward prohibitive fees charged by out-

Debat, Humberto, \& Babini, Dominique. (2020). Plan S in Latin America: A Precautionary Note. Scholarly and Research Communication, 11(1): 0101347, 12 pp. 
sourced private, for-profit publishers (Mukunth, 2019). As pointed out by John Holmwood (2018): "private benefit is adopting the mantle of public value and, if the advocates of commercialisation succeed, the loss will be that of the public in whose name it is taking place" (par. 17). In a plausible context in which APC levels are inaccessible to the Global South, Latin American researchers would be able to read but not to publish in international journals (Poynder, 2019).

Could it be, as suggested by Richard Poynder (2018), that the Global South may "not have to sign Plan S ... to benefit from ... it" (par. 22) and should "focus on supporting existing APC-free journals and creating new ones for the publish element, and negotiate citizen-wide national licensing deals ... for the read element" (par. 26)? Anubha Sinha (2019), questioning the proposal that India join Plan S, stated that: "it makes little sense for developing countries to spend an enormous amount on APCs demanded by a foreign publishing oligopoly ... Plan $S$ is not exactly a breakthrough plan for the global south as it does not sufficiently undercut the market power of the oligopoly" (par. 19). A recent report highlights that mean publication costs for a scholarly article are approximately US\$400, ranging from less than US\$200 to over US\$1,000 per article in peer-reviewed journals that have rejection rates of more than 90 percent of submissions (Grossman \& Brembs, 2019). Nevertheless, the Journal of Open Source Software publishes articles with internal costs of less than US\$10 (Tennant, 2018). In addition, while not a journal and thus without the associated costs of peer review, the preprint server arXiv post articles at less than US\$5 (Cornell University Library, 2010). In this scenario, it is also worth discussing during the global transition to full open access, alternative cost-effective initiatives. Plan $U$ proposes a funders mandate on preprint deposition that could lead to immediate access to scientific research, if peer-review is decoupled from publishing and post-publication evolves in new models of communitybased peer assessment (Sever, Eisen, \& Inglis, 2019). This “publish first, curate second" approach could accelerate the dissemination of scholarly outputs, eventually leading to a more rapid advancement of the research enterprise (Sarabipour, Debat, Emmott, Burgess, Schwessinger, \& Hensel, 2019; Stern \& O’Shea, 2019).

In sum, it is important to question asymmetrical discussions where privileged institutions unilaterally draft and commit the forthcoming global scholarly publishing landscape. A more reasonable and inclusive agenda where nations and institutions of diverse realities may participate in the scientific discourse and propose a fair, equilibrated, and rational ecosystem for the future of publishing should be embraced. At the verge of a fundamental shift in scholarly publishing there is a need to substantiate much-needed further dialogue with a focus on the regional consequences of proposed agreements and the contemplation of Latin American traditions and realities (Alperin, Babini, Chan, Gray, Guedon, Joseph, Rodrigues, Shearer, \& Vessuri, 2015). As stated recently by representatives of the African Open Science Platform, AmeliCA, cOAlition S, OA2020, and SciELO (São Paulo Statement on Open Access - Joint Declaration, 2019), there is an agreement with the ultimate goal of Plan S that all scholarly publications be published as open access to provide "universal, unrestricted, and immediate Open Access to scholarly information ... achieved through a variety of approaches" (par. 4-5) and scientific knowledge be considered as a global public good. Nonetheless, in line with Arianna Becerril-García, chair of AmeliCA, who stated that "The commer-

Debat, Humberto, \& Babini, Dominique. (2020). Plan S in Latin America: A Precautionary Note. Scholarly and Research Communication, 11(1): 0101347, 12 pp.
VOLUME 11 / ISSUE 1 / 2020 


\section{Scholarly and Research}

\section{Communication}

VOLUME 11 / ISSUE 1 / 2020 cial strategies that for-profit publishers have adopted for open access are ravenous, exclusionary and unsustainable. This is entirely contrary to the vision of open access that AmeliCA supports" (Poynder, 2019), the implementation guidelines of Plan S do not demonstrate how publishers will provide transparent costing and pricing and acceptable prices for less privileged institutions and countries. For a region that has an open access-funding model where each institution and country subsidizes its own publications, paying APCs at international market value will surely divert scarce resources available to support the non-commercial model in Latin America or, even worse, promote an APC business model in the region. Why should open access be a market? As mentioned by J. Alperin in his open review of this article: "The problem of Plan S for the region, as I see it myself and understand it from this article, is that it undermines and undervalues the current approach on both philosophical and financial grounds." The future of open access global scholarly communications and open science will benefit from the existence of a growing number of institutions, countries, and regions that support and give priority to community-led nonprofit open access initiatives. This vision and these values are not reflected in Plan S.

\section{Concluding remarks}

Consequently, it seems reasonable for Latin America not to join Plan S and rather assess its first evaluation, which should verify and inform results and implications for less privileged countries and institutions. Latin America should strengthen its international networking activities with initiatives that invest in, and promote, open nonprofit scholarly-led infrastructures, services, research, and indicators, allowing the academy to regain control of scholarly communications and its indicators for evaluation, as is the case of COAR (2019), DOAJ (2020), the Global Alliance of Open Access Scholarly Communication Platforms (UNESCO, 2019), among other initiatives that have a strong presence in and the participation of developing regions.

\section{Competing interest statement}

The authors of this article work in agriculture (Debat) and social sciences (Babini) research networks, which together with health, are among disciplines with a tradition of also publishing in quality regional journals, in local languages. In addition, Debat is an eLife and ASAPbio ambassador and a bioRxiv Affiliate. Babini is employed by CLACSO and represents CLACSO at AmeliCA-Open Knowledge. She is the Latin America content contributor for UNESCO-Global Open Access Portal and is a member of the advisory board of DORA; the Experts Committee of Science and Technology Digital Repositories National System, Argentina; the advisory board of Open Access India; Publi.ca (Canada), and a board member of the Redalyc-CLACSO collection of 930 social science journals.

\section{Acknowledgements}

This article was first posted as a preprint in English (Debat \& Babini, 2019a) and Spanish (Debat \& Babini, 2019b). The authors thank the reviews from Juan Pablo Alperin and anonymous reviewer B, which helped to improve this opinion article. 


\section{References}

ARG (2013) Act 26,899: Institutional Open Access Digital Repositories. URL: http://servicios.infoleg .gob.ar/infolegInternet/anexos/220000-224999/223459/norma.htm [June 10, 2019].

ALLEA. (2018). Systemic reforms and further consultation needed to make Plan S a success. URL: https: //www.allea.org/systemic-reforms-and-further-consultation-needed-to-make-plan-s-a-success/ [June 10, 2019].

Alperin, J.P. (2015). The public impact of Latin America's approach to open access [Doctoral dissertation]. Stanford, CA: Stanford University. URL: https://stacks.stanford.edu/file/druid:jr256tk1194 /AlperinDissertationFinalPublicImpact-augmented.pdf [June 10, 2019].

Alperin, J.P. (2016). Research is also for non-scholars: Lessons from Latin America [Conference presentation]. URL: https://figshare.com/articles/Research_is_also_for_non_scholars_Lessons_from _Latin_America/3187551 [June 10, 2019].

Alperin, J.P., Babini, D., Chan, L., Gray, E., Guedon, J-C., Joseph, H., Rodrigues, E., Shearer, K., \& Vessuri, E. (2015). Open Access in Latin America: A paragon for the rest of the world. SPARC. URL: https://sparcopen.org/news/2015/open-access-in-latin-america-a-paragon-for-the-rest-of-the -world/ [June 10, 2019].

AmeliCA. (2019a). Ameli, conocimiento abierto para América Latina y el Sur Global. URL: http://www. amelica.org/ [June 10, 2019].

AmeliCA. (2019b). Que es Ameli, conocimiento abierto para América Latina y el Sur Global. URL http://www.amelica.org/en/index.php/que-es-ameli/ [June 10, 2019].

Argentina. (n.d.). Sistema nacional de repositorios digitales. URL: http://repositoriosdigitales.mincyt .gob.ar/ [June 10, 2019].

ARG-EU. (2019). Joint communiqué. XI joint steering committee meeting of the bilateral agreement on science and technology between the European Union and Argentina. URL: http://ec.europa.eu /research/iscp/pdf/policy/ec_rtd_jc-11th-jscm-eu-ar_062019.pdf [June 10, 2019].

Babini, D. (2019). La comunicación científica en América Latina es abierta, colaborativa y no comercial: desafíos para las revistas. Palabra Clave (La Plata), 8(2), e065, 1-6. doi: 10.24215 /18539912e065

Babini, D., \& Machin-Mastromatteo, J.D. (2015). Latin American science is meant to be open access: Initiatives and current challenges. Information Development, 31(5), 477-481. doi: 10.1177 /0266666915601420

Baum, B., \& Coen, E. (2019). Evolution or revolution? Changing the way science is published and communicated. PLoS biology, 17(6), e3000272, 1-5. doi: 10.1371/journal.pbio.3000272

Becerril-García, A., \& Aguado-López, E. (2018). The end of a centralized open access project and the beginning of a community-based sustainable infrastructure for Latin America: Redalyc.org after fifteen years the open access ecosystem in Latin America. ELPUB 2018, 1-13. URL: https://hal .archives-ouvertes.fr/hal-01816693/ [June 10, 2019].

Becerril-García, A. (2019). AmeliCA vs Plan S: Same target, two different strategies to achieve open access. URL: http://www.amelica.org/en/index.php/2019/o1/10/amelica-vs-plan-s-mismo -objetivo-dos-estrategias-distintas-para-lograr-el-acceso-abierto/ [June 10, 2019].

Brainard, J. (2019). Scientific societies worry about threat from Plan S. Science, 363(6425) 332-333. doi: $10.1126 /$ science.363.6425.332

Carignano, H., \& Jaworski, J.P. (2019). Argentina's subpar investment in science. Science, 363(6428), 702. doi: $10.1126 /$ science.aaw 3872

Debat, Humberto, \& Babini, Dominique. (2020). Plan S in Latin America: A Precautionary Note. Scholarly and Research Communication, 11(1): 0101347, 12 pp.
Scholarly and Research

Communication

VOLUME 11 / ISSUE 1 / 2020 


\section{Scholarly and Research Communication}

VOLUME 11 / ISSUE 1 / 2020
CLACSO. (2015). CLACSO's declaration on open access to knowledge managed as a commons by the scholarly community. URL: https://www.clacso.org.ar/conferencia2015/documentos/asamblea /declaraciones/CLACSO-Declaration-on-open-access-to-knowledge-managed-as-a-commons -by-the-scholarly-community.pdf [June 10, 2019].

Clarke, M. (2018). Plan S: Impact on society publishers. Scholarly Kitchen. URL: https://scholarly kitchen.sspnet.org/2018/12/05/plan-s-impact-on-society-publishers/ [June 10, 2019].

cOAlition S. (2019a). Plan S: Principles and implementation. URL: https://www.coalition-s.org /principles-and-implementation/ [June 10, 2019].

cOAlition S. (2019b). Plan S: Funders. URL: https://www.coalition-s.org/funders/ [June 10, 2019].

cOAlition S. (2019c). Feedback on the draft implementation guidance of Plan S [Data set]. Zenodo. URL: https://zenodo.org/record/3250081/\#.XQoRWLxKiUm [June 19, 2019].

COAR: Confederation of open access repositories. (2019). URL: https://www.coar-repositories.org/ [June 10, 2019].

Consorcios de Iberamérica y el Caribe. (2017). URL: http://reuniondeconsorcios.conricyt.mx/index .php/primera-reunion/declaraciones/?lang=en [June 10, 2019].

Cornell University Library. (2010). arXiv Business model white paper. URL: https://arxiv.org/help /support/whitepaper [June 10, 2019].

de Knecht, S. (2019). The death of the learned societies? ScienceGuide. URL: https://www.scienceguide .nl/2019/06/the-death-of-the-learned-societies/ [June 10, 2019].

Debat, H., \& Babini, D. (2019a). Plan S in Latin America: A precautionary note. PeerJ Preprints, 7 , e27834V2, 1-11. doi: 10.7287/peerj.preprints.27834V2

Debat, H., \& Babini, D. (2019b). Plan S en América Latina: Una nota de precaución. Zenodo, 1-11. doi: 10.5281 /zenodo. 3332621

DOAJ. (2020). Directory of open access journals. URL: https://doaj.org/ [November 17, 2019].

DORA. (n.d.). San Francisco declaration on research assessment. URL: https://sfdora.org/ [June 10, 2019].

Figshare. (2019). Plan S and the Global South - links to comments on concerns. URL: https://figshare .com/articles/Plan_S_and_the_Global_South_-_links_to_comments_on_concerns/10078634 [November 17, 2019].

Frantsvåg, J.E., \& Strømme, T.E. (2019). Few open access journals are compliant with Plan S. Publications, 7 (2), 26, 1-18. doi: 10.3390/publications7020026

Grossmann, A., \& Brembs, B. (2019). Assessing the size of the affordability problem in scholarly publishing. PeerJ Preprints, 7, e27809v1, 1-44. doi: 10.7287/peerj.preprints.27809v1

Guédon, J-C. (2018). The history of the open access and its meaning [Video]. ISSN 2018 Conference. URL: https://webcast.in2p3.fr/video/the-history-of-the-open-access-and-its-meaning [November $17,2019]$.

Holmwood, J. (2018). The expansion of open access is being driven by commercialisation, where private benefit is adopting the mantle of public value. LSE Impact Blog. London, UK: London School of Economics. URL: https://blogs.lse.ac.uk/impactofsocialsciences/2018/10/o2/the-expansion-of -open-access-is-being-driven-by-commercialisation-where-private-benefit-is-adopting-the -mantle-of-public-value/ [June 10, 2019].

Mukunth, Vasudevan. (2019). India will skip Plan S, focus on national efforts in science publishing. The Wire. URL: https://thewire.in/the-sciences/plan-s-open-access-scientific-publishing-article -processing-charge-insa-k-vijayraghavan [November 17, 2019].

Kowaltowski, A.J., \& Oliveira, M.F. (2019). Plan S: Unrealistic capped fee structure. Science, 363(6426), 461. doi: 10.1126/science.aaw5815 [June 10, 2019].

LA Referencia. (n.d.). About us. URL: http://www.lareferencia.info/en/institutional/about-us [June 10, 2019].

Debat, Humberto, \& Babini, Dominique. (2020). Plan S in Latin America: A Precautionary Note. Scholarly and Research Communication, 11(1): 0101347, 12 pp. 
LA Referencia. (2019). Scholarly communication and open access actions for a public policy in Latin America. URL: http://www.lareferencia.info/es/recursos/ciencia-abierta-documentos-externos /93-scholarly-communication-and-open-access [June 10, 2019].

Larivière, V., Haustein, S., \& Mongeon, P. (2015). The oligopoly of academic publishers in the digital era. PloS one, 1o(6), e0127502, 1-44. doi: 10.1371/journal.pone.0127502

McNutt, M. (2019). Opinion: "Plan S" falls short for society publishers-and for the researchers they serve. Proceedings of the National Academy of Sciences, 116(7), 2400-2403. doi: 10.1073/pnas .1900359116

Mudditt, A. (2019). Plan S and the transformation of scholarly communication: Are we missing the woods? Scholarly Kitchen. URL: https://scholarlykitchen.sspnet.org/2019/06/o3/plan-s-and-the -transformation-of-scholarly-communication-are-we-missing-the-woods/ [June 10, 2019].

Mukunth, V. (2019). Six concerns over India joining the Plan S coalition for science journals. The Wire. URL: https://thewire.in/the-sciences/six-concerns-over-india-joining-the-plan-s-coalition -for-science-journals [June 10, 2019].

OA2020 - Open Access 2020. (2015). URL: https://oa2020.org [November 17, 2019].

Plan S Open Letter. (2019). Reaction of researchers to Plan S: Too far, too risky? URL: https://sites .google.com/view/plansopenletter/open-letter [June 10, 2019].

Poynder, R. (2019a). Plan S and the Global South: What do countries in the Global South stand to gain from signing up to Europe's open access strategy? LSE Impact Blog. London, UK: London School of Economics. URL: https://blogs.lse.ac.uk/impactofsocialsciences/2019/03/o6/plan-s-and -the-global-south-what-do-countries-in-the-global-south-stand-to-gain-from-signing-up-to -europes-open-access-strategy/ [June 10, 2019].

Poynder, R. (2019b). The OA interviews: Arianna Becerril-García, Chair of AmeliCA. URL: https:// poynder.blogspot.com/2019/05/the-oa-interviews-arianna-becerril.html [July 10, 2019].

Pulverer, B. (2018). Open access-or open science? The EMBO Journal, 37(24), e101215, 1-3. doi: 10.1002/embj.2018101215

Purton, M., Michelangeli, F., \& Fésüs, L. (2019). Will Plan S put learned societies in jeopardy? FEBS letters, 593(4), 383-385. doi: 10.1002/1873-3468.13333

Red de Revistas Científicas de América Latina y el Caribe, España y Portugal. (2019). URL: http://www .redalyc.org/ [June 10, 2019].

Roman, V. (2018). Argentina’s economic crisis could trigger scientific "collapse," researchers warn. Science. doi: 10.1126/science.aav5602

São Paulo Statement on Open Access - Joint Declaration. (2019). URL: https://www.coalition-s.org/wp -content/uploads/Sao-Paulo-Statement-OA-01052019.pdf [July 10, 2019].

Sarabipour, S., Debat, H. J., Emmott, E., Burgess, S. J., Schwessinger, B., \& Hensel, Z. (2019). On the value of preprints: An early career researcher perspective. PLoS biology, 17(2), e3000151, 1-12. doi: 10.1371/journal.pbio.3000151

Sayer, L. (2019). Plan S and open access in Latin America: Interview with Dominique Babini. International Science Council Blog. URL: https://council.science/current/blog/plan-s-and-open -access-interview-with-dominique-babini [June 10, 2019].

Sever, R., Eisen, M., \& Inglis, J. (2019). Plan U: Universal access to scientific and medical research via funder preprint mandates. PLoS biology, 17(6), e3000273, 1-4. doi: 10.1371/journal.pbio.3000273

Sinha, A. (2019). Should India adopt Plan $S$ to realise open access to public-funded scientific research? Access To Knowledge. Stanford, CA: Center for Internet and Society. URL: https://cis-india.org/a2k /blogs/should-india-adopt-plan-s-to-realise-open-access-to-public-funded-scientific-research [June 10, 2019].
Scholarly and Research Communication

VOLUME 11 / ISSUE 1 / 2020 
Scholarly and Research

\section{Communication}

VOLUME 11 / ISSUE 1 / 2020
Society Publishers' Coalition. (2019). Plan S consultation response from the Society Publishers' Coalition. URL: https://www.biologists.com/wp-content/uploads/SPC-Consultation-Response-8 -Feb-2019.pdf [June 10, 2019].

SPARC Europe. (2019). SPARC Europe analysis of the new revised Plan S policy. URL: https://sparc europe.org/briefing_revisedplans_june2019/ [June 10, 2019].

Stern, B.M., \& O’Shea, E.K. (2019). A proposal for the future of scientific publishing in the life sciences. PLoS biology, 17(2), e3000116, 1-10. doi: 10.1371/journal.pbio.3000116

Tennant, J. (2018). Why the term "Article Processing Charge" (APC) is misleading. Green Tea and Velociraptors Blog. URL: http://fossilsandshit.com/the-term-article-processing-charge-is -misleading/ [June 10, 2019].

Tennant, J. (2019). Plan S: Time to decide what we stand for. LSE Impact Blog. London, UK: London School of Economics. URL: https://blogs.lse.ac.uk/impactofsocialsciences/2019/03/05/plan-s -time-to-decide-what-we-stand-for/ [June 10, 2019].

UNESCO. (2017). Global open access portal, Latin America and the Caribbean: Argentina. URL: http://www.unesco.org/new/en/communication-and-information/portals-and-platforms/goap /access-by-region/latin-america-and-the-caribbean/argentina/ [June 10, 2019].

UNESCO. (2019). Global alliance of open access scholarly communication platforms. URL: https:// en.unesco.org/news/launch-global-alliance-open-access-scholarly-communication-platforms -democratize-knowledge [November 17, 2019].

Wessel, L. (2019a). Austerity cuts threaten future of science in Argentina. Science, 364(6439), 419. doi: $10.1126 /$ science.364.6439.419

Wessel, L. (2019b). Thousands of scientists in Argentina strike to protest budget cuts. Science Magazine. doi: 10.1126/science.aax8765

Willinsky, J. (2018, April 18). El acceso al conocimiento científico es un derecho humano. El País, 28. URL: https://elpais.com/elpais/2018/04/25/ciencia/1524672252_074648.html [November 17, 2019].

Zhang, Xiaolin. (2019). OA2020 Mainland China signatory libraries responded to Plan S guidance on implementation. (2019). URL: http://mailman.ecs.soton.ac.uk/pipermail/goal/2019-March /005095.html [June 10, 2019]. 